\author{
U.I. Kopzhasarova $^{1 *}$, D.E. Sagatkarim ${ }^{1}$, A.K. Shaimerdenova ${ }^{1}$, N. Stanchiu ${ }^{2}$ \\ ${ }^{1}$ Karagandy University of the name of academician E.A. Buketov, Kazakhstan; \\ ${ }^{2}$ University of Belgrade, Serbia \\ (*Corresponding author's e-mail: umit-55-hope@mail.ru)
}

\title{
Development of foreign language professional skills of chemistry specialty students
}

\begin{abstract}
The article focuses on the problem of the development of foreign language professional knowledge and skills of chemistry specialty students, which is acquiring special attention in the framework of growing role of foreign language communication in the professional work of modern specialists at the international labor market. The analysis of scientific literary sources on the problem under research has been carried out; in the framework of which specific features of foreign language teaching and learning process and also peculiarities of future work of chemistry specialty students have been revealed. Essential ways of the development and improvement of the foreign language communicative skills of future specialists in the chemical field, including methods and techniques used at professional foreign language classes with some practical examples have been considered. For improvement of independent work abilities and foreign-language professional communicative skills of students the authors suggest active methods and technologies aimed at problem setting and solving such as debates, discussions, business games, projects and case-study. In authors' opinion one of the effective methods of teaching and learning a professional foreign language is CLIL technology, its advantages and some difficulties in application have been also analyzed in the given research paper.
\end{abstract}

Keywords: foreign language professional skills, educational standards, modernization, internationalization, integrated learning, knowledge, innovative technologies.

Currently the higher education in Kazakhstan is undergoing significant changes associated with the adoption of new state educational standards, social transformations, scientific and technological modernization. The dynamic development of technology and computerization, the expansion of communication in the field of economics and production, modernization of education system and science are followed by significant changes in social needs of proficiency and competency of modern workers.

In March 2010 Kazakhstan officially joined the Bologna Declaration, which caused tremendous changes in the education system [1]. The state actively began to allocate funds for student's academic mobility, which created opportunities for the expansion of scientific and professional contacts, opening up opportunities for the study and work abroad.

Internationalization of education and science, globalization processes in economics and business testify that foreign language education is becoming one of the essential requirements of the university graduates. In addition, the rapid increase in the volume and pace of information exchange, the growth of economic and international cooperation, and the development of information and communication technologies actualizes the need of foreign language knowledge and proficiency. The widespread use of new information technologies and the Internet in professional activity puts forward new requirements for knowledge and competency level of foreign language specialists.

The level of foreign language proficiency of university graduates should create good conditions for their future professional development and acquaintance with the latest innovative technologies, discoveries and trends in science and technology, and also for establishing professional contacts and communication with foreign partners and colleagues. In other words, learning foreign languages at university should have a clearly expressed professional-oriented character; i.e. training students for professional communication in foreign language and their becoming competitive specialists capable to work at international labor market.

According to the fundamental documents of European Federation of National Engineering Associations (FEANI) the requirements for the competencies of engineers include not only the availability of relevant training, professional knowledge and academic skills (analytical, research, design, assessment skills etc.), personal skills (communication, compliance with a code of ethics), but also high level of foreign language knowledge and skills for communication and work with colleagues [2].

During studying at the Faculty of Natural Sciences, we acknowledged that the number of students, who are aware of the importance of foreign language knowledge and skills, is increasing every year. Students 
who speak foreign languages fluently have the opportunity for studying abroad through the academic mobility program; they also have good opportunity for participating at international conferences, sharing knowledge with foreign students online, reading and analyzing special professional literature; and most importantly, finding a job at international company in future.

The development of foreign language professional skills of university students is an integral part of education. The university graduates must have a high level of foreign language knowledge in the field of professional work; not only read and translate texts in their specialty, but also develop oral and written communicative skills (resumes, business letters, and other business correspondence) in English at professional level; therefore professional orientation of training requires the integration of a foreign language with relevant disciplines; educational materials should be focused on the latest achievements in a particular field of activity, reflect scientific discoveries and innovations, relating to the professional interests of students and give them opportunity for professional growth.

According to some researchers, an essential factor in the development and improvement of the foreign language communicative skills of specialists in their professional field is the increase of motivation, interest and awareness of the usefulness of the formed skills [3].

Considering foreign language knowledge as a means of development of the professional orientation of future specialists, Russian scientist E.V. Roshchina notes that in the framework of training professionaloriented language, a two-way connection is established: between the student's desire to acquire special knowledge and the success of mastery the language [4, p. 3-6].

She considers a foreign language as an effective means of professional and social orientation at nonlinguistic universities. According to the author, for its realization the following conditions must be followed:

- clear setting of the goals of foreign language speech activity;

- social and professional orientation of this activity;

- student satisfaction in solving particular problems;

- development of students' creative skills in solving particular problems;

- favorable psychological climate in group work.

In E.A. Shaturnaya's opinion, the development and formation of foreign language professional competency within professional-oriented communication, teaching will be more effective if the following conditions are followed:

- teaching and learning is based on a personal-activity approach;

- selection of the content of professional-oriented foreign language communication training is carried out on a case-thematic basis;

- authentic materials, selected within linguistic, methodological, cultural parameters and principles of teaching professional-oriented foreign language communication are used as training tools;

- training is carried out on the basis of a specially developed methodology, implying the use of activities and techniques aimed at development of foreign language professional competence of technical specialty students while teaching professional oriented foreign language communication $[5, \mathrm{p} .151-$ 154].

Since in the given paper we are dealing with the development of foreign language professional knowledge and skills of students of the specialty «Chemistry», we will consider the specific features of the future professional activity of graduates of the given specialty. After graduation bachelor graduates can work as chemistry teachers at schools, colleges and higher educational institutions; as laboratory assistants, as engineers at university laboratories and at research institutes of chemical, environmental and other profiles.

Learning a professional-oriented foreign language by students of the specialty «Chemistry» is carried out through the study of the discipline «Professional-oriented foreign language», which is a continuation of the course «Foreign Language (English)», «Basic English Language Course (Level A2-B1)», the result of which is the development of students basic skills in four types of speech activity: speaking, listening, reading and writing. At the same time, students improve their foreign language knowledge and skills in the given sphere within the framework of basic and major disciplines, taking into account the specifics of the specialty «Chemistry».

In the given context, one of the innovative pedagogical technologies that meet the requirements of integrated learning a foreign language and specialized disciplines is CLIL technology (Content and Language Integrated Learning). In the framework of CLIL technology, professional foreign language training is conducted through the content of a future profession. This method is an effective means of teaching students' 
professional foreign language communication. With the introduction of trilingual education, CLIL technology is actively used in the educational process of schools and higher educational institutions in Kazakhstan.

What is the essence of CLIL technology?

The term itself was coined by David Marsh (University of Jyväskylä, Finland) in early 1994, he wrote that «CLIL refers to situations in which academic subjects or part of academic subjects are studied in a foreign language and have the dual purpose of studying the subject while studying foreign language» [6]. The use of this technology in multilingual groups is the most appropriate. First of all, we need to consider the model of the lesson itself, using this technology and also its components [7]. Each lesson consists of four «C», so it includes the following:

- Content - the development of knowledge, skills in a specific subject area;

- Communication - the use of a foreign language during training;

- Cognition - the development of cognitive abilities of students;

- Culture - the presentation of oneself as part of the culture, as well as the awareness of the existence of alternative cultures.

One of the developers of CLIL technology, British professor of pedagogy Do Coyle connects the application of this technology with the internationalization of education and the introduction of English into the educational process of higher education [8, p. 103-119].

Despite the abundance of scientific views on approaches to CLIL technology, researchers adhere to the ideas of the Finnish scientist David Marsh that a foreign language acts as a tool for studying the content of a non-linguistic subject of specialized discipline.

The content of practical classes in professional-oriented English within the framework of CLIL technology involves the improvement of students' foreign language knowledge and skills in all types of speech activity: listening, speaking, reading and writing. At the same time, special emphasis is placed on immersion in working with professional text. This form of work is necessary for the development of skills to understand and analyze texts of general content, general scientific, popular science specialized texts in their future profession.

CLIL settings can provide more opportunities for practical activities, which tend to produce more involved interaction as student center approach to teaching process as well as more content based learning and collaborative forms of work [9]. Working in small groups can increase both the quantity and quality of the lesson. In the framework of problem-solving activities without teacher's control, students are aware of the tasks and problems to be solved; so consequently learners do their best to achieve their goals and objectives $[10$, p. 392-400].

It should be noted that reading texts on specialty at foreign language classes allows students to understand and comprehend specific terms, certain language structures, which contribute to the expansion of student vocabulary with subject terminology and prepares them for further study and application of the knowledge and skills in the field of future professional work.

It is also necessary to read authentic professional oriented texts in the framework of future specialty. Scientific texts differ from other types of texts in both language and structure. They lack a plot and emotional coloring, but there are a large number of special terminologies. During reading authentic professionaloriented texts students increase their ability to identify the necessary information from the proposed material in order to use it further.

To select texts and develop reading skills of chemical specialty students teachers rely on the principles of a cognitive-communicative methodology in a foreign language teaching. Widely used methodology in the United States and Canada is called CALLA (Cognitive Academic Language Learning Approach) [11, p. 150-155]. This method helps students comprehend and develop foreign language skills and knowledge. The main aim of CALLA is to give opportunity for students to learn foreign language independently and become self-educated learners.

According to the standard curriculum, students of the specialty "Chemistry» study such sections of chemistry as organic, inorganic, quantum, analytical, and physicochemical. In the framework of which students study the following topics: «The Basics of Chemical Bonding», «The Quantum Mechanical Atom», «The Quantum Mechanical Atom», «Oxidation - Reduction Reactions, Introduction to orbitals», «Molecular orbital description of bonding, hybridization, structure of methane», «Alkanes-conformational analysis, structural isomerism and nomenclature, alkyl groups», «Nuclear Magnetic Resonance (NMR) spectroscopy», «Uncertainty principle», «Operators, eigenfunctions, eigenvalues» etc. 
At the present time ready gained knowledge is replaced by independent learning of students; which, in its turn, implies a change in the style of relations between the teacher and the student, student and the educational environment [12, p. 853-865]. The transition from pedagogical influence to pedagogical interaction is one of the conditions for the search and realization of effective methods in the framework of teaching foreign languages.

To improve independent work abilities and foreign-language professional communicative skills of students, it is advisable to use methods and activities aimed at problem solution such as debates, discussions, business games, projects, case-studies, which focus on the development of their analytical, evaluative, reflective skills in a foreign language. On the one hand within these methods CLIL technology is actively used: specific terminology in English is learnt, and further used in different communicative situations; on the other hand methods listed above develop students' independent learning skills during setting and solving problems within the learning process. Students develop their foreign language knowledge and skills through different types of reading texts on specialty. They are: detailed, skimming, scanning reading etc., they promote improvement of their oral and written communicative skills within the subject «English for specific purposes».

Debates can be used for the systematization and consolidation of educational material for improvement of foreign language knowledge and communicative skills using specific terminology. It is more advisable to use the debate at the final stage of studying any material or topic. For instance, «The invention and widespread use of plastics» can be discussed by students on debate. In the framework of preparation for debates students make research to the given topic and analyze various types of literature. The next important stage of debate is setting and solution of problems by students themselves.

At professionally oriented foreign language practical classes discussion with elements of game modeling, a round-table discussion can be also conducted, where a small group of participants discusses a problem and the rest of the team members participate in an exchange of views. For a productive discussion, it is necessary to precede it with speech exercises that contain special terminology and contribute to the practicing of lexical units occurring during the discussion. The discussion allows the teacher and students to come to a joint solution of the issue. Chemical analysis of various kinds of fuel, used at the present time, might become an interesting subject for discussion. To conduct a discussion on the given topic students need to select a moderator who will follow the discussion. Students participating in the discussion share their opinions and impressions with their groupmates. After the speech of all participants, the moderator summarizes the discussed problem. During the discussion and exchange of views, students learn about different types of fuel (solid, liquid and gas), moreover they discuss the most appropriate types of chemical analyses. The invaluable benefit of the educational discussion is that the work is held in an interactive way; all students of the group are involved in the discussion, which allows the teacher to evaluate the opinions of all participants. The teacher, as the coordinator of the discussion, can also participate in the discussion of the given problem. During the discussion, students activate lexical and grammatical thematic material, develop and improve mental, analytical, communicative skills in a foreign language; justifying and defending their point of view students develop speaking skills in public. Another method of improving independent work abilities and foreign-language professional communicative skills of students is developing projects on a range of actual topics starting with food or environmental chemistry ending with biochemistry or nanochemistry. Project works increase students' motivation, interest and desire to learn and enhance foreign language skills, and more importantly, during the implementation of the project in a foreign language students learn to independently acquire knowledge, gain experience in cognitive and educational activities, improve their phonetic and grammatical skills, and also replenish their vocabulary. The project technology is characterized by high level of students' communicative activity and interaction, it involves the defense, justification of student's thoughts, feelings and relationships [13, p. 20].

One of the most effective techniques in teaching and learning foreign languages is the use of business games. Business games as a method of active learning have a number of advantages, which imply their practical orientation: as a rule the structure and content of the game follows the interests and needs of students. This form of organization of educational activity is characterized by a combination of practical and theoretical aspects in training, setting the problem and the possibility of solving them in practice.

In accordance with the purposes of use business games can be: educational, production and research. In the context of our work, we will consider educational and research games. Educational business games have more practical orientation. Participants of educational business game should understand the importance of the given problems and be aware that they will set and solve problems during carrying out professional activities [14]. According to the Model Curriculum, a business game can be held on the topic «Allotropes of car- 
bon». Preparation for the game begins with the development of a business game plan: setting goals, problems and tasks of the lesson; identifying the characters of the game. The procedure of the game is structured in the following way: group presentation, mutual exchange of views on the issue and conclusion.

Another effective method in the framework of teaching professional English to chemistry specialty students at university is using virtual labs during practical lessons. Experimental videos can transfer students to a virtual world of molecules, molar masses, and complex equations. Virtual labs are one of the most effective ways for chemistry teachers to engage their students in active learning [15, p. 56-59]. Virtual labs are an excellent way for students to realize their own potential, involving them in the image of their future work. Students become actively engaged, when they start applying their theoretical knowledge in the real working process. Transforming from teacher-centered to student-centered learning can enable students to actively learn and fully engage in their own activity without the teacher's help and support. Laboratory instruction is and should be a central component of every chemistry class. There are many online programs where students can develop models and 3D models of compounds, provide online experiments and solve chemical equations. All these programs function in English, so the need to learn and know English for students in the chemical field increases. There are some examples of such websites: acs.org, masteringchemistry.com, nstrument.com.cn, chemspider.com, chemieonline.de etc.

After studying and analyzing the literature on the issue and taking into consideration our own experience in learning a professional-oriented foreign language, we highlight the following advantages of using CLIL technology:

- increase of the motivation of students;

- development of the analytical and critical thinking skills of students;

- engaging students in the language environment;

- obtaining more extensive knowledge for future professional communication;

- development of foreign language competence of students;

- improvement of the cognitive abilities of students;

- integration of the subject area and language, as a result of which the foreign language vocabulary in the specialty is replenished.

Along with this, there are certain difficulties in using this technology: the deficiency of English textbooks, the insufficient number of hours for the discipline study, the different levels of foreign language knowledge of students.

Summing up the problem of improving the foreign language professional skills of students, we conclude that the preparation of qualified competitive specialists for work at the international labor market requires not only proficiency and competency in the field of a particular specialty. A determining factor for the successful professional career of the university graduates at the international labor market is the high level of their foreign language professional skills. The CLIL technology, used at foreign language classes in a proper way is an effective tool for the development of learners' foreign language professional communicative skills. Methodically coordinated teaching of a subject discipline and a foreign language is widely used in the international educational community due to its versatility and easy adaptation.

\section{References}

1 Концепция развития иноязычного образования // Вестн. КазУМОиМЯ. - 2008. — № 2(98). - С. $20-22$.

2 Levy F. The New Division of Labor: How Computers Are Creating the next Job Market / F. Levy, R.J. Murnane. - New York: Russell Sage Foundation, 2004.

3 Wiesemes R. The Final Report for the Content and Language Integrated Project / R. Wiesemes. — London: CILT, 2005.

4 Рошина Е.В. Функции иностранного языка как учебного предмета системного обучения в университете / Е.В. Рошина // Иностранные языки на специальных факультетах. — М., 1978. - С. 3-6.

5 Покушалова Л.В. Формирование иноязычной и профессионально-ориентированной компетенции у студентов технического вуза / Л.В. Покушалова // Молодой ученый. — 2011. — Т. 2, № 3. - С. 151-154.

6 Бибикова Е.В. Особенности профессионально-ориентированного обучения иностранному языку в неязыковом вузе / Е.В. Бибикова // Материалы III Междунар. науч.-практ. конф. - Красноярск, 2016. - С. 96-100.

7 Marsh D. CLIL. The European Dimension: Actions, Trends and Foresight Potential Public Services Contract DG EAC / D. Marsh. - European Commission, 2002.

8 Light D. Increasing Student Engagement in Math: The Use of Khan Academy in Chilean Classrooms / D. Light, E. Pierson // International Journal of Education and Development Using Information and Communication Technology. — 2014. - Vol. 10. P. 103-119. 
9 Nunan D. Communicative tasks and the language curriculum / D. Nunan // Tesol Quarterly. — 1991. — Vol. 25, Iss. 2. P. 279-295.

10 Волков Н.Г. Личность преподавателя и новые технологии обучения в иностранном вузе / Н.Г. Волков // Вестн. Казан. нац. исслед. технол. ун-та. — 2012. — № 10. — Р. 392-400.

11 Васильева У.С. Основания для выбора методов обучения иностранным языкам в современных условиях / У.С. Васильева // Современные модели в преподавании языков и культур в контексте менеджмента качества образования. - M., 2009. - C. 150-155.

12 Dalgarno B. Effectiveness of a Virtual Laboratory as a preparatory resource for Distance Education chemistry students / B. Dalgarno, A. Bishop, W. Adlong, D. Bedgood // Computers \& Education. - 2009. - Vol. 53. - P. 853-865.

13 Hutchinson T. Introduction to Project Work / T. Hutchinson. - Oxford University Press, 2001. — P. 23.

14 Barthlow M. The Effectiveness of Process-Oriented Guide Inquiry Learning to Reduce Alternative Conceptions in Secondary Chemistry / M. Barthlow, S.Watson // School science and Mathematics. - 2014. - Vol. 114, Iss.5. — P. $246-255$.

15 Squire K., Jenkins H. Video games and learning / K. Squire, H. Jenkins. — New York: Teachers, 2011. — P. 56-59.

\title{
У.И. Копжасарова, Д.Е. Сағаткәрім, А.К. Шаймерденова, Н. Станчю
}

\section{«Химия» мамандығының студенттеріне шетел тілінің кәсіби біліктілігін дамыту}

\begin{abstract}
Мақалада қазіргі таңда халықаралық еңбек нарығындағы мамандарға кәсіби шетел тілінің біліктілігіне қойылып отырған талаптардың артуына байланысты химия мамандығы студенттерінің шетел тілінің кәсіби білімі мен іскерлігін дамыту мәселесіне баса назар аударылған. Зерттеу тақырыбы бойынша ғылыми әдеби дереккөздерге талдау жүргізілген; оның аясында шетел тілін оқу және оқыту үрдісінің өзіндік ерекшеліктері, сонымен қатар «Химия» мамандығы студенттерінің болашақ жұмысының ерекшеліктері анықталған. «Химия» саласы бойынша болашақ мамандардың шетел тілінде коммуникативтік біліктілігін дамыту мен жетілдірудің негізгі жолдары, соның ішінде кейбір практикалық мысалдармен шетел тілі бойынша кәсіби сабақтарда қолданылатын әдістер мен тәсілдер қарастырылған. Студенттердің өзіндік жұмыс істеу дағдыларын және шетел тілінде кәсіби коммуникативтік құзыреттілігін жетілдіру үшін авторлар дебаттар, пікірталастар, іскерлік ойындар, жобалар мен кейс-стади сияқты мәселелерді қою мен шешуге бағытталған белсенді әдістер мен технологияларды ұсынған. Авторлардың пікірінше, кәсіби шетел тілін оқыту мен оқытудың тиімді әдістерінің бірі CLIL технологиясы болып табылады, бұл жұмыста оның артықшылықтары мен қолданудағы кейбір қиындықтар талданған.
\end{abstract}

Кілт сөздер: шет тілін меңгерудің кәсіби дағдылары, білім беру стандарттары, жаңғырту, интернационализация, интеграцияланған оқыту, білім, инновациялық технологиялар.

\section{У.И. Копжасарова, Д.Е. Сагаткарим, А.К. Шаймерденова, Н. Станчю \\ Развитие иноязычных профессиональных умений студентов специальности «Химия»}

Статья посвящена проблеме развития иноязычных профессиональных знаний и умений студентов химической специальности, которая приобретает особое значение в рамках возрастающей роли иноязычного общения в профессиональной деятельности современных специалистов на международном рынке труда. Проведен анализ научных литературных источников по исследуемой проблеме, в рамках которого были выявлены специфические особенности процесса обучения профессиональному иностранному языку, а также специфика будущей работы студентов химической специальности. Рассмотрены основные пути развития и совершенствования иноязычных коммуникативных умений будущих специалистов химической отрасли, в том числе методы и приемы, используемые на занятиях по профессионально-ориентированному иностранному языку, с некоторыми практическими примерами. Для совершенствования навыков самостоятельной работы и иноязычной профессиональной коммуникативной компетенции студентов авторами предложены активные методы и технологии, направленные на постановку и решение проблем, таких как дебаты, дискуссии, деловые игры, проекты и кейс-стади. По мнению авторов, одним из эффективных методов обучения профессиональному иностранному языку является технология CLIL, в данной работе проанализированы ее преимущества и некоторые трудности в применении.

Ключевые слова: профессиональные навыки владения иностранным языком, образовательные стандарты, модернизация, интернационализация, интегрированное обучение, знания, инновационные технологии. 


\section{References}

1 Kontseptsiia razvitiia inoiazychnoho obrazovaniia [The concept of development of foreign language education]. (2008). Vestnik KazUMOiMY imeni Abylai khana - Bulletin of Kazakh Ablai khan university of international relations and world languages, 2(98), 20-22 [in Russian].

2 Levy, F., \& Murnane, R.J. (2004). The New Division of Labor: How Computers Are Creating the next Job Market. New York: Russell Sage Foundation.

3 Wiesemes, R. (2005). The Final Report for the Content and Language Integrated Project, London, CILT.

4 Roshina, E.V. (1978). Funktsii inostrannoho yazyka kak uchebnoho predmeta sistemnoho obucheniia $\mathrm{v}$ universitete [Functions of a foreign language as a subject of systemic education at the university]. Inostrannye yazyki na spetsialnykh fakultetakh - Foreign languages at special faculties, Moscow, 3-6 [in Russian].

5 Pokushalova, L.V. (2011). Formirovanie inoiazychnoi i professionalno-orientirovannoi kompetentsii u studentov tekhnicheskoho vuza [The formation of foreign and professionally-oriented competence among students of a technical university]. Molodoi uchenyi - Young scientist, 2, 3, 151-154 [in Russian].

6 Bibikova, E.V. (2016). Osobennosti professionalno-orientirovannoho obucheniia inostrannomu yazyku v neiazykovom vuze [Features of vocational-oriented teaching of a foreign language in a non-linguistic university]. Proceedings from: III Mezhdunarodnaia nauchno-prakticheskaia konferentsiia - III International Scientific and Practical Conference (p. 96-100), Krasnoyarsk [in Russian].

7 Marsh, D. (2002). CLIL. The European Dimension: Actions, Trends and Foresight Potential Public Services Contract DG EAC, European Commission.

8 Light, D., Pierson, E. (2014). Increasing Student Engagement in Math: The Use of Khan Academy in Chilean Classrooms, International Journal of Education and Development Using Information and Communication Technology, 10, $103-119$.

9 Nunan, D. (1991). Communicative tasks and the language curriculum, Tesol Quarterly, 25(2), $279-295$.

10 Volkov, N.G. (2012). Lichnost prepodavatelia i novye tekhnolohii obucheniia v innovatsionnom vuze [Personalities of the teacher and new teaching technologies at an innovative university]. Vestnik Kazanskoho natsionalnoho issledovatelskoho tekhnolohicheskoho universiteta - Bulletin of Kazan National Research Technological University, 10, $392-400$ [in Russian].

11 Vasilieva, U.S. (2009). Osnovaniia dlia vybora metodov obucheniia inostrannym yazykam v sovremennykh usloviiakh [Reasons for choosing methods of teaching foreign languages in modern conditions]. Sovremennye modeli v prepodavanii yazykov $i$ kultur $v$ kontekste menedzhmenta kachestva obrazovaniia - Modern models in the teaching of languages and cultures in the context of education quality management, Moscow [in Russian].

12 Dalgarno, B., Bishop, A., Adlong, W., \& Bedgood, D. (2009). Effectiveness of a Virtual Laboratory as a preparatory resource for Distance Education chemistry students. Computers \& Education, 53, 853-865.

13 Hutchinson, T. (2001). Introduction to Project Work. Oxford University Press.

14 Barthlow, M., Watson, S. (2014). The Effectiveness of Process-Oriented Guide Inquiry Learning to Reduce Alternative Conceptions in Secondary Chemistry, School science and Mathematics, 114(5), 246-255.

15 Squire, K, Jenkins, H. (2011). Video games and learning. New York: Teachers. 